\title{
Defense of Host Plants against Orgyia trigotephras in Northeast of Tunisia
}

\begin{abstract}
Olfa Ezzine, Laboratoire d'Ecologie Forestière (LR161INRGREF03), INRGREF, Université de Carthage, 2080 Ariana, Tunisia, Hnia Chograni, Département de Biologie, INS AT, Université de Carthage, 1080 Tunis, Tunisia, Samir Dhahri and Mohamed Lahbib Ben Jamâa, Laboratoire de Gestion et de Valorisation des Ressources Forestières (LR161INRGREF01) INRGREF, Université de Carthage, 2080 Ariana, Tunisia

https://doi.org/10.52543/tjpp.15.2.5

(Tunisia)
\end{abstract}

\begin{abstract}
Ezzine, O., Chograni, H., Dhahri, S., and Ben Jamâa, M.L. 2020. Defense of host plants against Orgyia trigotephras in north-east Tunisia. Tunisian Journal of Plant Protection 15 (2): 81-89.

The egg-larval stage of Orgyia trigotephras were observed in shrubs maquis of Jebel Abderrahmane in north-east Tunisia, mainly on Quercus coccifera and Pistacia lentiscus, while only eggs were noticed on Phillyrea media. This kind of observation suggest us to study tree defense against $O$. trigotephras which will be explored by chemical analysis of $P$. lentiscus, $Q$. coccifera and $P$. media. Two types of analyses were the focus of this study to understand plant defense (i) primary metabolites and (ii) components of essential oils of these tested plants. Kjeldhal method was used for nitrogen and Mrssorr method for potassium, sodium and phosphorus extraction. Essential oils were extracted with the hexane solvent; chemical composition was determined using (GC/MS) methods. Oil compounds were identified by comparison to their retention time. Results of mineral extraction showed that percentage of potassium, sodium, phosphorus and nitrogen were more important in P. lentiscus and $P$. media than in $Q$. coccifera. Five major compounds were identified from essential oils of $Q$. coccifera, four from $P$. media and four from P. lentiscus. Nitrogen, which is a source of protein for insects, is produced in low concentrations in the foliage, decreasing nitrogen levels strategy for defending the plant against insect larvae. The absence of monoterpens in the foliage at $P$. media could explain the choice of larvae not to feed upon this host which probably confers resistance against this defoliator.
\end{abstract}

Keywords: Defense, essentials oil, minerals, Orgyia trigotephras, Tunisia

Plants, as a food source, have a considerable role in the dynamics of herbivorous insect populations due to their nutritive components (proteins,

Corresponding author: Olfa Ezzine

Email: olfa.ezzine@gmail.com

Accepted for publication 10 December 2020 amino acids, carbohydrates, lipids, vitamins, minerals, water, etc.) and nonnutritional components (allelochemical compounds such as phenols, terpenes, glucosinolates, alkaloids, etc.) (Ohgushi 1992). Some chemicals substances released by infested plants are the result of mechanical disturbance of plant cells and therefore are not specific to the herbivore. However, other volatile products released as a result of damage 
are specific indicators for phyllophagous (Dicke et al. 1990).

The species Orgyia trigotephras (Lepidoptera, Erebidae) is distributed around the Mediterranean area, from Anatolia (Patočka and Turčáni 2008) to the Southwestern Europe, France (Bérard et al. 2010), Iberian Peninsula (Cifuentes 1997; Montoya and Masmano 1993) to the Northern Africa: Morocco (Villemant and Fraval 1993), Algeria (Rungs 1981) and Tunisia (Chénour 1955; Ezzine et al. 2010; Lord Rothschild et al. 1917).

Despite its polyphagia, $O$. trigotephras preferentially attacks oak species (Villemant and Fraval 1993). In Tunisia, larvae and egg batches of $O$. trigotephras were observed on Pistacia lentiscus, Q. coccifera (Ezzine et al. 2010), Halimium halimifolium (Ezzine et al. 2015), Calicotome villosa, Erica multiflora and E. arborea (Ezzine 2016). On Phillyrea media, only egg batches were observed (Ezzine 2016).

To highlight plant response to herbivore attack, we propose to study the defense mechanisms (direct and indirect) of $P$. lentiscus, $Q$. coccifera and $P$. media against $O$. trigotephras. In this work we aimed to (i) analyze secondary metabolites and (ii) estimate the importance of minerals of the tested plants.

\section{MATERIALS AND METHODS Study site.}

This study was conducted using harvested biological material, from the outbreak site of $O$. trigotephras, in the northeastern of Tunisia (Jebel Abderrahmane, Cap Bon) in Delhiza (alt. $401 \mathrm{~m}, 36^{\circ} 51^{\prime} \mathrm{N}, 10^{\circ} 47^{\prime} \mathrm{E}$ ) in 2009 . The vegetation at the site is composed of Mediterranean maquis with 12 main plant species. Most abundant species were Cistus crispus, C. villosus, Erica arborea, E. multiflora and Phillyrea media. The two species $P$. lentiscus and $Q$. coccifera occurred at similar intermediate densities. Other plant species occurred only rarely (Ampelodesmos mauritanicus and Chamaerops humilis) or with low constancy (Calicotome villosa, C. monspeliensis and Daphne gnidium). Plant identification was carried out using plant guides (Schoenenberger et al. 1971; DGF 1995).

\section{Collecting samples.}

Leaves of $P$. lentiscus, $Q$. coccifera and $P$. media were collected in October 2009, dried in the shade and conserved for the chemical analysis: nitrogen $(\mathrm{N})$, potassium $(\mathrm{K})$, sodium $(\mathrm{Na})$ and phosphorus $(\mathrm{P})$ and the essential oil extraction.

\section{Mineral extraction.}

The total nitrogen was measured using the Kjeldhal method (Jackson 1958). This method required 3 steps: mineralization, distillation and titration. The percentage of nitrogen was obtained by the following equation:

$$
\mathrm{N}(\%)=0.7 \times \mathrm{n} / \mathrm{w} \times 100,
$$

with $1 \mathrm{ml}$ of $\mathrm{HCl} \mathrm{N} / 20$, n: quantity $\mathrm{ml}$ of $\mathrm{HCl}$ added to the sample and w: the weight of the vegetable powder $(\mathrm{w}=100$ $\mathrm{mg}$ ). The assay was performed according to Mrssorr's method, ammonium phosphovanadomolybdate (Bray and Kurty 1945). The rate of each compound was calculated by the following equation: Compound rate $(\%)=(\mathrm{RS} \times \mathrm{Cs} / \mathrm{Rs} \times \mathrm{V} /$ Ws 1000$) \times 100$,

with RS: reading of the sample, Rs: reading of the standard, Cs: concentration of the standard, $\mathrm{V}$ : volume of the sample $(50 \mathrm{ml})$ and Ws: weight of the sample (500 mg).

\section{Essential oils extraction.}

Dried and prepared leaves were crushed in a mortar containing liquid 
nitrogen until obtaining a powder. An amount of $1 \mathrm{~g}$ of powder was mixed with $10 \mathrm{ml}$ of absolute methanol. Essential oils were extracted with the hexane solvent (Ressoug et al. 2005). The content of obtained essential oils (EOs) was dried over anhydrous sodium sulphate, and stored at $-4^{\circ} \mathrm{C}$ until analysis. Assessment of the chemical composition of plant species EOs was carried out by gas chromatography/mass

spectrometry (GC/MS) methods (Messaoud et al. 2005). The GC-MS unit consisted of a Perkin-Elmer Auto-system XL gas chromatograph, equipped with HP INNOWAX capillary column (Agilent 6280, $30 \mathrm{~m} \times 0.25 \mathrm{~mm}$, film thickness $0.25 \mu \mathrm{m})$ and interfaced with PerkinElmer Turbo mass spectrometer (Software version 4.1). The operating conditions were as follows: the injector temperature was $250^{\circ} \mathrm{C}$; carrier gas was helium at $2 \mathrm{ml} / \mathrm{min}$; a volume of $2 \mu \mathrm{l}$ of each sample was injected in split mode; ion source temperature was $280^{\circ} \mathrm{C}$. The temperature gradient started at $50^{\circ} \mathrm{C}$, raised to $220^{\circ} \mathrm{C}\left(8^{\circ} \mathrm{C} / \mathrm{min}\right)$, then to $220^{\circ} \mathrm{C}$ $\left(10^{\circ} \mathrm{C} / \mathrm{min}\right)$. Oil components were identified by comparison to their retention indices determined with reference to a homologous series of $\mathrm{C}_{9}-\mathrm{C}_{24}$ of $\mathrm{n}$-alkanes with those of authentic standards (Koroch et al. 2007). Identification was confirmed by comparison of their mass spectra with those recorded in the NIST08 and W8N08 libraries.

\section{Data analysis.}

The statistical analysis was performed using the SPSS-10.0 software package for Windows. Average of the different quantity of mineral composition were reported as mean percentage. Results were statistically evaluated by using analysis of variance (ANOVA) and complemented by multiple comparisons of means by the SNK test (StudentNewman-Keuls) at $95 \%$ confidence interval $(P<0.05)$. Results were expressed as mean \pm standard error of mean (MSE).

\section{RESULTS \\ Mineral analysis.}

Results of mineral extraction was significant between the three plant species with $\left(\mathrm{F}_{(2,6)}=12.777, P=0.007\right)$ for phosphorus, $\left(\mathrm{F}_{(2,6)}=6.883, P=0.028\right)$ for potassium and $\left(\mathrm{F}_{(2,6)}=5.645, P=\right.$ 0.042 ) for sodium. The percentage of phosphorus $(\mathrm{P})$, potassium $(\mathrm{K})$ and sodium $(\mathrm{Na})$ was more important in $P$. lentiscus $\left(3.28 \pm 0.18710^{-5} \%, 0.69 \pm\right.$ $0.012 \%$ and $0.72 \pm 0.02 \%$, respectively) and $P$. media $\left(2.9510^{-5} \%, 0.63 \%\right.$ and $0.53 \%$, respectively) than in $Q$. coccifera (Fig. 1). Regarding the nitrogen concentration, there was no difference between the three plant species analyses $\left(\mathrm{F}_{(2,6)}=3.618, P=0.093\right)$. It was $2.13 \pm$ $0.08 \%$ for $Q$. coccifera and $2.59 \pm$ $0.181 \%$ for P. media (Fig. 1 ).

\section{Essential oil contents and composition.}

The monoterpenes and sesquiterpenes were observed in $Q$. coccifera, $P$. lentiscus and ranged respectively from $14.19 \%$ and $95.64 \%$. The diterpenes were observed in all species, with a low rate on $P$. lentiscus $(2.03 \%)$. The triterpenes were observed in $Q$. coccifera, and $P$. media with respectively $50.81 \%$ and $63.4 \%$ (Table 1 ).

Five major compounds were identified from EOs of $Q$. coccifera, four from $P$. media and four from P. lentiscus. Betulinic acid, Betulin, $\beta$-Sitosterol and Sitost-4-en-3-one were in common between $Q$. coccifera and $P$. media (Table 1). 


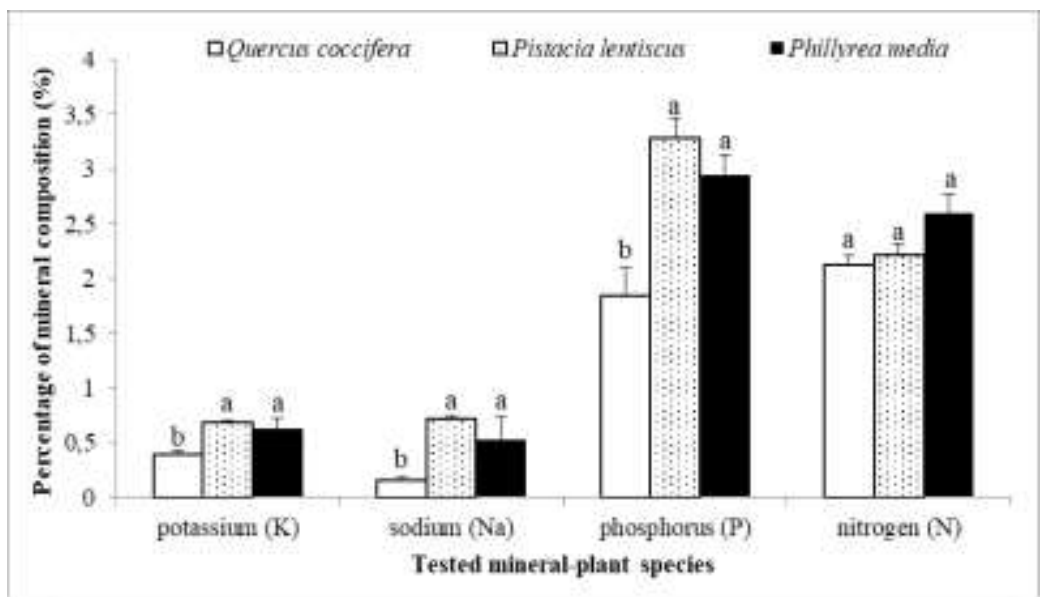

Fig. 1. Mineral compound (K, Na, P, N) rates of Quercus coccifera, Phillyrea lentiscus, Pistacia media. Each value represents the mean of three replicates \pm SE. Values with different letters are significantly different at $P<0.05$.

Table 1. Rate of the major essential oil compounds in the three tested species Quercus coccifera, Phillyrea media and Pistacia lentiscus

\begin{tabular}{|c|c|c|c|c|}
\hline Compounds & RI & Q. coccifera & P. media & P. lentiscus \\
\hline$\alpha$-Pinene & 938 & $\operatorname{tr}$ & $\operatorname{tr}$ & 4 \\
\hline$\alpha$-Bisabolol & 1581 & 7.69 & $\operatorname{tr}$ & 2.33 \\
\hline$\beta$-Caryophyllene & 1366 & $\operatorname{tr}$ & $\operatorname{tr}$ & 12.85 \\
\hline Germacrene D & 1418 & $\operatorname{tr}$ & $\operatorname{tr}$ & 11.67 \\
\hline Caryophyllene oxyde & 1486 & $\operatorname{tr}$ & $\operatorname{tr}$ & 4.58 \\
\hline Betulinic acid & 1674 & 4.22 & 9 & $\operatorname{tr}$ \\
\hline Betulin & 1689 & 12.1 & 13 & $\operatorname{tr}$ \\
\hline$\beta$-Sitosterol & 1718 & 5.1 & 6.8 & $\operatorname{tr}$ \\
\hline Sitost-4-en-3-one & 1764 & 9.22 & 12 & $\operatorname{tr}$ \\
\hline \multicolumn{2}{|c|}{ Monoterpenes and Sesquiterpenes (\%) } & 14.19 & 0 & 95.64 \\
\hline \multicolumn{2}{|l|}{ Diterpenes (\%) } & 27.87 & 36.56 & 2.03 \\
\hline \multicolumn{2}{|l|}{ Triterpenes (\%) } & 50.81 & 63.4 & 0 \\
\hline \multicolumn{2}{|c|}{ Total (\%) } & 92.87 & 99.96 & 97.67 \\
\hline
\end{tabular}




\section{DISCUSSION}

Plants and insects co-evoluate together, both have evolved strategies to avoid each other's defense systems (War et al. 2012). Direct defenses such as the production of toxic chemicals kill or retard the development of the herbivores (Hanley et al. 2007). In our work, we observed high rates of monoterpenes and sesquiterpenes in $P$. lentiscus that may have repellent effect on larvae of $O$. trigotephras. In fact, defensive components of the plant may affect the fitness and behavior of the herbivores (War et al. 2011). Studies conducted by Ezzine et al. (2010) on larvae of $O$. trigotephras reared on $Q$. coccifera and $P$. lentiscus showed that larvae have a relatively long development time and adults are relatively small when larvae feed on $P$. lentiscus. Furthermore, egg batches contain a high proportion of unfertilized eggs. Contrary to $Q$. coccifera, the lentisk is not favorable for the development of $O$. trigotephras.

Staudt et al. (2001) showed that attack of $Q$. ilex by larvae of the Erebidae, Lymantria dispar induce the emission of volatile organic compounds (VOCs). In fact, the stress induced by the emission of VOCs by attacked plants allows the release of reactive molecules (sesquiterpenes and monoterpenes) (Staudt and Lhoutellier 2007). The induced VOCs have a direct and protective role by dissuading defoliators and indirect, by attraction of their natural enemies (Kessler and Baldwin 2001; Thaler et al. 2001). The absence of monoterpenes in $P$. media can explain the no-choice of larvae of $O$. trigotephras to this species. Nitrogen reduction can be a defense strategy against herbivores (Feeny 1976). Nitrogen, as a source of protein for insects, is produced in low concentrations in the foliage of the host plant (Slansky and Feeny 1977). Casotti and Bradley (1991) showed that attacked foliage of Eucalyptus species may decrease its nitrogen concentration. Ezzine (2016) showed that larvae of the $1^{\text {st }}, 2^{\text {nd }}$ and $3^{\text {rd }}$ instars of $O$. trigotephras imperatively feed on kermes oak; mature larvae feed on other shrub species mainly $P$. lentiscus. In years of high population density (2009 and 2014), most late-instar larvae of $O$. trigotephras moved to $P$. lentiscus, possibly due to the previous high exploitation of $Q$. coccifera by young larvae (Ezzine et al. 2015a) that may probably decrease the nitrogen concentration in the host plant. A rearing of larvae of $O$. trigotephras conducted by Ezzine (2016) on $Q$. coccifera and $P$. lentiscus showed that larvae pass through five larval stages. Contrariwise, on $P$. media, larvae pupate directly after the fourth instar, whereas this species contains a significant amount of nitrogen. Potassium and phosphorus are essentials for the physiology and the development of the insect (Dadd 1985; Mattson and Scriber 1978). Research conducted by Daryaei et al. (2008) on L. dispar showed that physico-chemical characteristics of clones of Populus $\times$ Euramericana have a considerable effect not only on the choice of the insect but also on nutritional indexes. Clones of Populus are chosen because of the important quantity of nutrients: $2.5 \%$ of nitrogen, 0.25 to $0.41 \%$ of phosphorous and 0.5 to $1.5 \%$ of potassium. The same thing was observed for $O$. trigotephras; the important quantity of these compounds on $Q$. coccifera and $P$. lentiscus allowed a good development of larvae. Ezzine et al. (2015a) showed that levels of defoliation of $Q$. coccifera by larvae of $O$. trigotephras reached almost $100 \%$ during the outbreak peak (2009) while they were always lower for $P$. lentiscus. Moreover, a test choice of larvae of $O$. trigotephras released in the lab on $Q$. coccifera, $Q$. 
suber, P. lentiscus, $P$. media, $C$. monoplienisis, E. multiflora and $D$. gnidium showed that larvae choose the two oak species to feed (Ezzine 2016). Thus, kermes oak seems to be crucial for the development of larvae of $O$. trigotephras. Plants that do not allow a good development of caterpillars have a better resistance against defoliator, as observed for $P$. media which did not allow a good development of larvae (low nutritional indices) and caused a high level of larval mortality (Ezzine et al. 2014). In the field, no larvae were observed on $P$. media; it seems that the secondary metabolites (toxins) confer a resistance for the plant. The benefit of a secondary substance, in terms of increased adaptative fitness in the presence of phytophagous pests is related to the decreased fitness due to production, transport, storage and use of secondary metabolites (Feeny 1976).

The study of plant/insect interactions must integrate the $3^{\text {rd }}$ trophic level (predators and parasitoids) as indirect defenses against insects (Price et al. 1980) mediated by the release of a blend of volatiles that specifically attract these natural enemies of the herbivores (Arimura et al. 2009). In fact, Harborne (1993) showed that each shrub species develops a chemical defense with which an entomofauna is associated and specialized.

\section{RESUME}

Ezzine O., Chograni H., Dhahri S. et Ben Jamâa M.L. 2020. Défense des plantes hôtes contre Orgyia trigotephras dans le nord-est de la Tunisie. Tunisian Journal of Plant Protection 15 (2): 81-89.

Les stades ovo-larvaires d'Orgyia trigotephras ont été observés dans le maquis de Jebel Abderrahmane dans le nord-est de la Tunisie, principalement sur Quercus coccifera et Pistacia lentiscus. Sur Phillyrea media seulement les pontes ont été notées. Ce type d'observation nous a incité à étudier la défense de la plante contre $O$. trigotephras qui sera examinée par l'analyse biochimique de $P$. lentiscus, $Q$. coccifera et $P$. media. Deux types d'analyses ont fait l'objet de ce travail pour comprendre la défense de la plante (i) les métabolites primaires et (ii) les composés des huiles essentielles de ces 3 espèces testées. La méthode Kjeldhal a été utilisée pour l'extraction de l'azote, celle de Mrssorr pour l'extraction du potassium, du sodium et du phosphore. Les huiles essentielles ont été extraites avec le solvant hexane; l'évaluation de la composition chimique a été réalisée par GC/MS. Les composés des huiles ont été identifiés par rapport à leur temps de rétention. Les résultats de l'extraction des minéraux ont montré que les pourcentages de potassium, de sodium, de phosphore et de l'azote étaient plus conséquents pour les espèces $P$. lentiscus et $P$. media que pour $Q$. coccifera. Cinq composés majoritaires ont été identifiés dans les huiles essentielles de $Q$. coccifera, quatre dans $P$. media et quatre dans $P$. lentiscus. L'azote, qui est une source de protéines pour les insectes, est produit en faibles concentrations dans le feuillage; la réduction de l'azote dans la plante hôte pourrait être une stratégie de défense développée par la plante contre les agressions des larves de cet insecte. L'absence des monoterpènes dans le feuillage de $P$. media explique le choix des larves de ne pas se nourrir sur cette espèce ce qui lui confère probablement une résistance contre ce défoliateur.

Mots clés: Défense, huiles essentielles, minéraux, Orgyia trigotephras, Tunisie

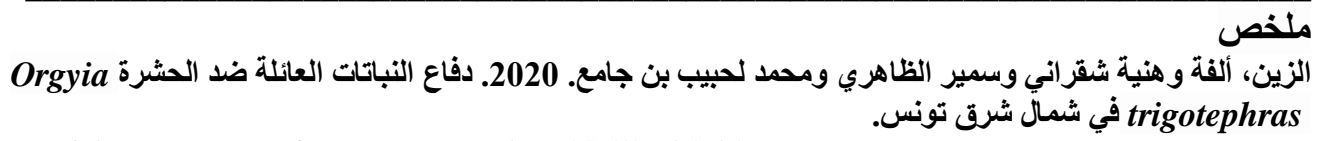

Tunisian Journal of Plant Protection 15 (2): 81-89. 
لوحظت يرقات وبيض Orgyia trigotephras علي الأحراش في جبل عبد الرحمان في شمال شرق تونس بشكل

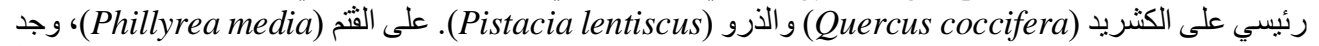
بيض فقط. دفعنا هذا النوع من الملاحظة إلى در اسة دفاع النبات ضد والند O. trigotephras التي سيتم فحصها من خلال

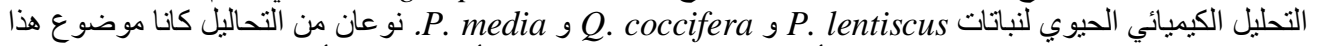

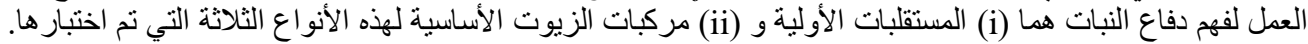

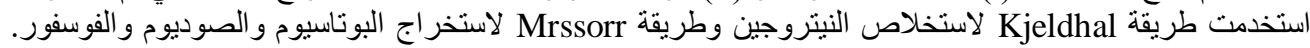

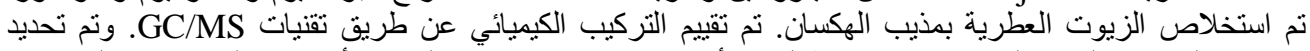

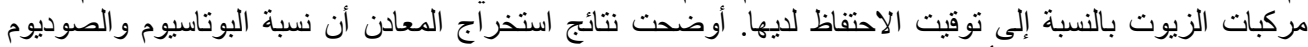

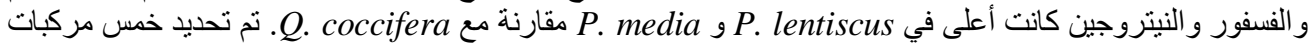

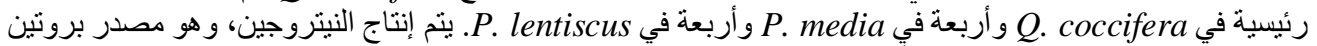

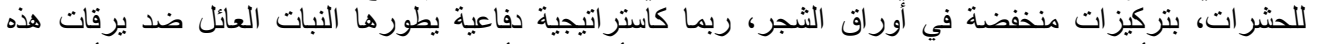

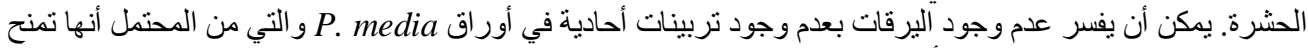

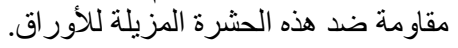

كلمات مفتاحية: نونس، دفاع، زيوت أساسية، معادن، Orgyia trigotephras

\section{LITERATURE CITED}

Arimura, G.I., Matsui, K., and Takabayashi, J. 2009. Chemical and molecular ecology of herbivoreinduced plant volatiles: proximate factors and their ultimate functions. Plant and Cell Physiology 50: 911-23.

Bérard, R., Bordon, J., Colomb, C., Savourey, M., Audibert, C., Rozier, Y., and Clary, J. 2010. Les Macrohétérocères de la Région RhôneAlpes. Les Cahiers du Musée des Confluences 1: 9-42.

Bray, R.H., and Kurty, L.T. 1945. Determination of total, organic and available forms of phosphorus in soils. Soil Science 59: 39-45.

Casotti, G., and Bradley, J.S. 1991. Leaf nitrogen and its effects on the rate of herbivory on selected eucalypts in the jarrah forest. Forest Ecolology ans Management 41: 167-177.

Chénour, A. 1955. Macrolépidoptères de Tunisie (Bombyces). Bulletin de la Société des Sciences Naturelles de Tunisie 8: 257-277.

Cifuentes, J. 1997. Los Thaumetopoeidae y Limantriidae (Lepidoptera) de Navarra (España). Boletín de la Asociación Española de Entomología 21: 49-60.

Dadd, R.H. 1985. Nutrition: organisms. Pages. 313390. In: Comprehensive Insect Physiology, Biochemistry and Pharmacology. G.A. Kerkut, Gilbert L.I., Eds., Editions Pergamon Press, Oxford, UK.

Dicke, M., Sabelies, M.W., Takabayashi, J., Bruin, J., and Posthumus, M.A. 1990. Plant strategies of manipulating predator-prey interactions through allelochemicals: prospects for application in pest control. Journal of Chemical Ecology 16: 3091-3118.
DGF 1995. Forêt domaniale de Béni Oualid. Plan d'aménagement 1996-2015. Direction générale des forêts. CRDA de Nabeul. SOGET Maghreb, Tunisia, 89 pp.

Daryaei, M.G., Darvishi, S., Etebari, K., and Salehi, M. 2008. Host Preference and Nutrition Efficiency of the Gypsy Moth, Lymantria dispar L. (Lymantriidae: Lepidoptera), on different Poplar Clones. Turkish Journal of Agriculture and Forestry 32: 469-477.

Ezzine, O., Ben Jamâa, M.L., M'nara, S., and Nouira, S. 2010. Bioécologie d'Orgyia trigotephras (Boisduval, 1829), (Lepidoptera, Lymantriidae) à Jebel Abderrahmane, Cap Bon (Nord Est de la Tunisie). Bulletin of the International Organisation for Biological and Integrated Control (WPRS) 57: 123-127.

Ezzine, O., Mannai, Y., Nouira, S., and Ben Jamâa, M.L. 2014. Les indices nutritionnels d'Orgyia trigotephras BOISDUVAL, 1829 (Lepidoptera, Lymantrïdae) sur cinq espèces $\mathrm{du}$ maquis. Bulletin of the International Organisation for Biological and Integrated Control (WPRS) 101: 187-194.

Ezzine, O., Hammami, S., Hausmann, A., Nouira, S., and Ben Jamâa, M.L. 2015. First Report of Anacampsis scintillela on Halimium halimifolium in Sejnane (Bizerte, Tunisia). Tunisian Journal of Plant Protection 10: 63-68.

Ezzine, O., Branco, M., Villemant, C., Schmidt, S., Nouira, S., and Ben Jamâa, M.L. 2015a. Host use in Orgyia trigotephras (Erebidae, Lymantriinae) during outbreak: effects on larval performance and egg mortality. Annals of Forest Science $72: 561-568$. 
Ezzine, O. 2016. Interactions insectes/plantes-hôtes : cas d'Orgyia trigotephras Boisduval (1829) (Lepidoptera, Erebidae) en Tunisie. Doctorate Thesis in Biological Sciences. Faculty of Sciences of Tunis, University of Carthage, Tunisia, $206 \mathrm{pp}$.

Feeny, P. 1976. Plant apparency and chemical defense. Recent Advances in Phytochemistry 10: 3-40.

Hanley, M.E., Lamont, B.B., Fairbanks, M.M., and Rafferty, C.M. 2007. Plant structural traits and their role in antiherbivore defense. Perspectives in Plant Ecology Evolution Systematics 8:157-78.

Harborne, J.B. 1993. Introduction to chemical ecology. Academic press, Editions, London, UK, 317 pp.

Jackson, M.L. 1958. Application of radioisotopes in the study of soils. Ministerio de Minas y Petroleos, Lab. Quimico Nacional Bogotá Columbia Bulletin 4: 26-55.

Kessler, A., and Baldwin, I.T. 2001. Defensive function of herbivore-induced plant volatile emissions in nature. Science 291: 2141-2144.

Koroch, A.R., Juliani, H.R., and Zygadlo, J.A. 2007. Bioactivity of essential oils and their components. Pages 87-115. In: Flavours and Fragrances: Chemistry, Bioprocessing and Sustainability. R.G. Berger, Ed., Springer, Berlin, Germany.

Lord Rothschild, F.R.S., Hartert, E., and Jordan, K. 1917. Novitates Zoologicae 24:325-438.

Ohgushi, T. 1992. Resource limitation on insect herbivore populations. Pages 199-241. In: Effects of resource distribution on animalplant interactions. M.D. Hunter, T. Ohgushi, P.W. Price, Eds., Academic Press Inc, New York, USA.

Mattson, W.J., and Scriber, J.M. 1978. Nutritional Ecology of Insects Folivores of woody plants: nitrogen, water, fiber and mineral considerations. Pages 105-146. In: Nutritional Ecology of Insects, Mites, Spiders and Related Invertebrates. F. Jr Slansky, J.G. Rodriguez, Eds., Wiley \& Sons, New York, USA.

Messaoud, C., Zaouali, Y., Ben Salah, A., Khoudja M.L., and Boussaid, M. 2005. Myrtus communis in Tunisia: variability of the essential oil composition in natural populations. Flavour and Fragrance Journal 20: 577-582.

Montoya, J.A.M., and Masmano, M.B. 1993. Una contribución al estudio de los insectos defoliadores de la encina (Qeurcus ilex L.) en el noroeste de la provincia de Albacete. Revista de la Facultad de Educacion de Albacete 8: 281-288.

Patočka, J., and Turčáni, M. 2008. Contribution to the description of pupae of the western
Palaearctic Lymantriids (Lepidoptera, Lymantriidae). Linzer Biologische Beitrage 40: 901-920.

Price, P.W., Bouton, C.E., Gross, P., McPheron, B.A., Thompson, J.N., and Weis, A.E. 1980 Interactions among three trophic levels: Influence of plants on interactions between insect herbivores and natural enemies. Annual Review of Ecology Evolution and Systematics 11: 41-65.

Schoenenberger, A., Albert, E., Dimanche, P., Franclot, A., and Marion, J. 1971. Premiers enseignements des Arboretums Forestiers. Programme des Nations Unis pour le développement. Organisation des Nations Unies pour l'alimentation et l'agriculture, Rome, Italy, 178 pp.

Ressoug, S.A., Boutekedjiret C., and Allaf, K. 2005. Optimization of operating conditions of rosemary essential oil extraction by a fast controlled pressure drop process using response surface methodology. Journal of Food Engineering 71 : 9-17.

Rungs, Ch. 1981. Catalogues raisonnés des lépidoptères du Maroc. Inventaire faunistique et observations écologiques. Travaux de l'Institut Scientifique Séries Zoologie 40 : 224-228.

Slansky, F., and Feeny, P. 1977. Stabilization of the rate of nitrogen accumulation by larvae of the cabbage butterfly on wild and cultivated food plants. Ecological Monographs 47: 209-228.

Staudt, M., Joffre, R., Rambal, S., and Kesselmeier, J. 2001. Effect of elevated $\mathrm{CO}_{2}$ on monoterpene emission of young Quercus ilex trees and its relation to structural and ecophysiological parameters. Tree Physiology 21: 437-445

Staudt, M., and Lhoutellier, L. 2007. Volatile organic compound emission from holm oak infested by gypsy moth larvae: evidence for distinct responses in damaged and undamaged leaves. Tree Physiology 27: 1433-1440.

Thaler, J.S., Stout, M.J., Karban, R., and Duffey, S.S. 2001. Jasmonate-mediated induced plant resistance affects a community of herbivores. Ecological Entomology 26: 312-324.

Villemant, C., and Fraval, A. 1993. The insect fauna of the cork-oak tree in the Mamora forest (Morocco). Ecologia Mediterranea 19: 89-98.

War, A.R., Paulraj, M.G., War, M.Y., and Ignacimuthu, S. 2011. Jasmonic acidmediated induced resistance in groundnut (Arachis hypogaea L.) against Helicoverpa armigera (Hubner) (Lepidoptera: Noctuidae). Journal of Plant Growth Regulation 30: 512 23.

War, A.R., Paulraj, M.G., Ahmad, T., Buhroo, A.A., Hussain, B., Ignacimuthu, S., and Sharma, 
H.Ch. 2012. Mechanisms of Plant Defense 
